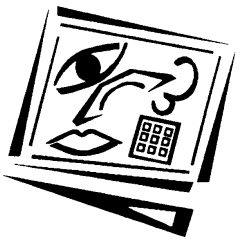

\title{
Advancing the $m$-learning research agenda for active, experiential learning: Four case studies
}

\author{
Laurel Evelyn Dyson, Andrew Litchfield, Elaine Lawrence, \\ Ryszard Raban and Peter Leijdekkers \\ University of Technology, Sydney
}

\begin{abstract}
This article reports on an m-learning research agenda instituted at our university in order to explore how mobile technology can enhance active, experiential learning. Details of the implementation and results of four areas of m-learning are presented: mobile supported fieldwork, fostering interactivity in large lectures with mobile technology, using mobile devices to learn about mobile technology and, finally, podcasting. These directions are informed by a concern for achieving m-learning practices consistent with sound educational theory and the needs of the contemporary, technologically aware student body. All four implementations have been successfully embedded in mainstream subjects on a continuing basis. Therefore they represent a departure from the project based approach of much m-learning reported in the literature. This outcome was achieved through a focus on the economic sustainability and feasibility of each case. An evaluation focusing on how well each case assisted students' learning found that, with the exception of lecture podcasting, all supported high quality experiential learning.
\end{abstract}

\section{Introduction}

The extraordinary growth in ownership of mobile devices in recent years is creating a growing interest in mobile learning (m-learning). We can define m-learning most simply as the facilitation of learning using mobile or hand held digital devices. These can include devices with wireless connectivity, such as mobile phones, PDAs (personal digital assistants), BlackBerries, GPS (global positioning system) receivers, clickers, laptops and tablet PCs, as well as iPods and MP3 players, which are increasingly becoming wireless enabled (Naismith, Lonsdale, Vavoula \& Sharples, 2004; KukulskaHulme \& Traxler, 2005). Furthermore, given the convergence in mobile technologies that is now under way, devices for facilitating m-learning may include other digital portable hardware, such as games consoles, digital cameras and video cameras (Kukulska-Hulme \& Traxler, 2005). Even memory sticks and USB flash drives have been employed in m-learning as they provide a "bridge between contexts of use" (JISC, 2005, p. 32).

M-learning implementations have been wide ranging and include podcasting, wireless access to online resources, interactive classroom activities, fieldwork, educational games, language learning, music education, student reminders and personal timetabling, work based training and lifelong learning, all using mobile devices of some kind (Naismith et. al., 2004; Kukulska-Hulme \& Traxler, 2005; JISC, 2005; Litchfield, Dyson, Lawrence \& Zmijewska, 2007). Much has been written about "anywhere, anytime" learning since the mid 1990s, and some writers have gone so far 
as to claim that m-learning inevitably involves students who are on the move, engaging in learning that occurs outside class (Sharples, Taylor \& Vavoula, 2005). Nevertheless, many practitioners would dispute that definition of m-learning as too narrow, given the great interest in using mobile devices to improve learning within all learning settings, including the classroom, in the field and in informal adult learning settings.

These technologies have the capability to transform higher education by making our educational approaches better aligned with the current technological practices of our students. Surveys conducted in Australia have consistently shown that at least 95\% of Australian students born since 1980 - the so-called "digital natives" (those who have grown up with computer technology) - now have mobile phones (Bachfischer, Lawrence, Litchfield, Dyson \& Raban, 2008; Oliver \& Goerke, 2007). In addition, many students have unrestricted access to digital cameras (76\%), MP3 players (69\%) and laptops (63\%) (Kennedy, Judd, Churchward, Gray \& Krause, 2008). Making phone calls and sending text messages are almost universal among student mobile phone owners, with $70 \%$ using their phone to take photographs or videos, and $53 \%$ sending these to other people over their phones (Kennedy et al, 2008). In one survey, $73 \%$ of students stated that they would be interested in using a mobile device in their studies (Lawrence, Bachfischer, Dyson \& Litchfield, 2008). It is time to incorporate m-learning into the university curriculum and into our educational design.

However, much still needs to be done to demonstrate how to enhance student learning through the use of these technologies. The priority must be to design an educational strategy for active, experiential m-learning. This might include, for example, mobile supported fieldwork, hands on learning, role plays and games. We need m-learning which places the student at the centre of the learning process, promotes collaboration, provides an understanding of the authentic context of knowledge, and encourages independent learning behaviour, so that students become lifelong learners (Naismith et al., 2004). Furthermore, from the perspective of higher education, m-learning must provide effective support for the learners' development of the generic "soft" skills necessary for their chosen career, that is, the graduate attributes associated with their profession (Litchfield, Nettleton \& Taylor, 2008).

Another priority should be embedding m-learning into mainstream educational practice. Moving from short term projects to sustainable, long term delivery represents one of the major challenges for m-learning (Traxler, 2005; Dyson, Raban, Litchfield \& Lawrence, 2008). Today m-learning is still in an exploratory phase, with few applications other than podcasting in widespread use (Dyson et al., 2008). Various issues have been identified as contributing to this situation, such as a lack of wireless infrastructure and technical support, the need for change management and proper evaluation of m-learning, as well as the resolving of any potential equity issues (Traxler, 2005). Both Traxler (2005) and Dyson et al. (2008) see cost as a major hurdle, with most m-learning projects terminating once the initial funding has been exhausted. Another issue is the feasibility of m-learning from the lecturer's viewpoint in terms of the effort required to introduce and then maintain the activity. Traxler $(2005$, p. 182) suggests the need for:

exemplar content, lessons and courses across a range of disciplines that give teachers a sense of what they themselves could achieve; some "quick-and-dirty" and hence not intimidating 
The authors address these priorities through firstly examining how learning with mobile technologies can support active, experiential, student-centred learning. Four implementations of m-learning from our university are then described (see Table 1) and evaluated against the main criterion of how well they support experiential learning, as well as in terms of their sustainability and practical feasibility. These implementations are 1 . mobile supported fieldwork, 2 . interactive m-learning in large lectures, 3. using mobile technology to learn about mobile technology and 4. podcasts of lecture summaries. It should be noted that none of these are short term projects, but represent a concerted effort to embed m-learning into mainstream courses. As such we believe that this record of our research and the analysis of its outcomes should be of great interest both to the educational technology community and to teachers contemplating their own m-learning experimentation for the first time.

Table 1: The m-learning research agenda and its relation to experiential learning theory

\begin{tabular}{|c|c|c|c|c|c|}
\hline \multirow{3}{*}{$\begin{array}{l}\text { Experiential } \\
\text { learning } \\
\text { cycle }\end{array}$} & \multicolumn{4}{|c|}{ Case studies } & \multirow{3}{*}{$\begin{array}{l}\text { Depth of } \\
\text { learning }\end{array}$} \\
\hline & M-fieldwork & $\begin{array}{l}\text { Interactive } \\
\text { lectures using } \\
\text { mInteract }\end{array}$ & $\begin{array}{c}\text { Mobile } \\
\text { application } \\
\text { development } \\
\text { with PDAs }\end{array}$ & $\begin{array}{l}\text { Lecture } \\
\text { summary } \\
\text { podcasts }\end{array}$ & \\
\hline & & & & $\begin{array}{l}\text { Passive } \\
\text { listening }\end{array}$ & \\
\hline $\begin{array}{c}\text { Active } \\
\text { experience }\end{array}$ & $\begin{array}{c}\text { Concrete } \\
\text { experience of } \\
\text { technologies in } \\
\text { context }\end{array}$ & $\begin{array}{l}\text { Actively } \\
\text { responding to } \\
\text { questions }\end{array}$ & $\begin{array}{l}\text { Mobile } \\
\text { programming on } \\
\text { real devices }\end{array}$ & & \\
\hline Reflection & $\begin{array}{c}\text { Team reflection } \\
\text { on fieldwork } \\
\text { while preparing } \\
\text { class } \\
\text { presentation }\end{array}$ & $\begin{array}{l}\text { Reflection on } \\
\text { display of class } \\
\text { results - "How } \\
\text { does my answer } \\
\text { compare?" }\end{array}$ & $\begin{array}{l}\text { Reflection on } \\
\text { mobile } \\
\text { programming }\end{array}$ & & \\
\hline $\begin{array}{l}\text { Abstract } \\
\text { conceptual- } \\
\text { isation }\end{array}$ & $\begin{array}{l}\text { Integration of } \\
\text { field experience } \\
\text { with theory in } \\
\text { presentation }\end{array}$ & $\begin{array}{l}\text { Confirmation or } \\
\text { rethinking of } \\
\text { theoretical } \\
\text { understanding }\end{array}$ & $\begin{array}{c}\text { Integration of } \\
\text { experience with } \\
\text { wireless } \\
\text { technology theory }\end{array}$ & $\begin{array}{l}\text { (Support for } \\
\text { application of } \\
\text { theory to other } \\
\text { experiences) }\end{array}$ & \\
\hline $\begin{array}{l}\text { Experim- } \\
\text { entation }\end{array}$ & $\begin{array}{l}\text { Application to } \\
\text { major field } \\
\text { assignment }\end{array}$ & $\begin{array}{l}\text { Application of } \\
\text { new } \\
\text { understandings } \\
\text { to assignments, } \\
\text { exams or work }\end{array}$ & $\begin{array}{c}\text { Future } \\
\text { experiences of } \\
\text { mobile } \\
\text { programming }\end{array}$ & & Deep \\
\hline
\end{tabular}

\section{Active, experiential learning for our students}

Prosser and Trigwell (1999), Marton and Booth (1997) and Ramsden (1992) have demonstrated that students who adopt deep approaches to learning achieve better learning outcomes than those who adopt surface approaches. Similarly, the greater the students' perceptions of the learning context, the better are their learning outcomes (Prosser \& Trigwell, 1999). Deep approaches are characterised by an orientation towards understanding, personal sense making and active learning. They include those strategies defined theoretically as: 
- Experiential: Learning results from the student's own experience of action in the real world, reflection on this experience leading to abstract conceptualisation, followed by experimentation with the new concepts so formed (Kolb, 1984)

- Constructivist: Learners actively build new knowledge by incorporating into their existing knowledge-base concepts derived from their educational experience (Bruner, 1966)

- Situated: Learners acquire knowledge through participating with others in a community of practice and within an authentic context (Lave \& Wenger, 1991).

"Authentic", "learner centred" and "active" are common descriptors for these approaches to education. In this paper, we have adopted the related terms "experiential learning" and "active learning" as a theoretical and methodological foundation for what we believe to be good educational practice in the 21st Century. In experiential learning, the student's active experience is the primary driving force from which learning comes. However, we also acknowledge the value of the other theories mentioned above, which have much in common with the experiential approach. All these models of learning are in sharp contrast with the traditional, didactic educational paradigm, where knowledge is an object to be transmitted from the teacher to the student, usually in the form of lectures or a textbook (Kay \& Dyson, 2004). Such a surface approach typically focuses on memorisation and the reproduction of knowledge, often characterised by a lack of personal engagement in the learning activity.

These considerations are important when introducing new technologies into learning. Mobile devices must be used to develop learning situations that will encourage students to adopt deep approaches to study, actively engage them in knowledge discovery, and improve their perceptions of the learning context. By these means students' overall educational experience and outcomes will be improved.

Herrington and Herrington (2007, p. 5) note the particular suitability of mobile technologies for active learning, for example, "as tools for complex and sustained tasks and problem solving". They list a number of mobile applications which support authentic learning activities, including student use of the multimedia capabilities of mobile devices for developing digital narratives, the gathering and analysis of field data, concept mapping, and student production of podcasts. Lai, Yang, Chen, Ho and Chan (2007) note the affordances that mobile technologies provide for experiential learning by allowing rapid "note taking" through photos, sound and video recording, and by supporting students through in field provision of learning materials and prompts to assist their development of abstract concepts.

By contrast with e-learning, m-learning lends itself to realistic settings and to informal learning away from the educational context of the classroom and library (Laouris \& Eteokleous, 2005). Naismith et al. (2004) note the potential of mobile technologies to transform our educational practices by moving learning outside the classroom, allowing learners to connect to resources and people anywhere, fostering collaboration and teamwork, and turning students into investigators through the publication of their observations.

Both Herrington and Herrington (2007) and Naismith et al. (2004), however, warn of the challenge to educators in achieving m-learning which is student centred. Indeed, Herrington and Herrington (2007) claim that most current use (content delivery) still 
perpetuates the didactic, transmission model of education. Therefore any research agenda for m-learning will need to move away from this into more active and experiential learning tasks centred on the student.

\section{Our m-learning research agenda}

In choosing which aspects of m-learning to explore (see Table 1 above), we were motivated by a number of factors.

Firstly, we realised that the focus must always be on those approaches which foster active, experiential learning. Generally, in selecting our implementations, we chose well in this regard. However, as will be seen in our presentation of the four case studies, podcasting did not live up to this foundational consideration once we had had time to reflect and evaluate. We have decided to include it in this article as it serves as a good contrast with our more successful cases.

Secondly, despite the award of an initial infrastructure grant from our university to buy 18 PDAs, it was realised that minimising costs would need to be a prime objective, given the climate of fiscal restraint in which Australian universities operate and the improbability of further grants to fund mobile equipment purchases. Neither was money available to pay usage charges. So economic sustainability was an important aspect of our agenda in order to ensure that m-learning became embedded into mainstream courses. This largely took the form of building m-learning activities around mobile devices which the students already owned (their mobile phones and other devices) and reducing their usage charges to a minimum.

Practicality was another concern. As busy academics running sometimes large classes we were interested in achieving improvements in learning which would be easy to manage and within our various levels of technical know how. Therefore, some of our implementations focused on quite simple uses of mobile technology.

Further considerations included the need to address the most pressing challenges facing us in our current teaching. For academics from the discipline of Information Technology (IT) there are constant issues with how to teach our students more effectively about technology, how to engage students in the large lectures of core subjects, and how to support these students, particularly when entering degree programs straight from school or from a different educational environment overseas. In addition, at the time of the launch of our m-learning research agenda, there took place a major redesign of our undergraduate IT program. This gave an opportunity to introduce the latest mobile technologies to interest our students (mostly digital natives) and to improve our learning and teaching strategies using m-learning.

\section{Case study one: Mobile supported fieldwork}

Fieldwork supported by mobile devices (m-fieldwork) has been a part of our new undergraduate degree program since the launch of the subject Introduction to Information Systems in 2007. This is a core first year, first semester subject for IT students and Business students undertaking a Business/IT double degree or an IT major. Attracting approximately 340 students in first semester and up to 110 students in the smaller mid-year intake, it poses real challenges in terms of managing mobile technology costs and streamlining coordination of the fieldwork. 
Fieldwork has long been identified as a way of allowing students to apply classroom theory to real life situations. Learning becomes situated in the context of a "time and location, ... the learner's trajectory, goals and motivation, the surrounding resources, co-learners, and other available conversants" (Sharples, Corlett \& Westmancott, 2002). It provides many of the elements of experiential learning as the active participation of the learner is uppermost. In this subject, fieldwork gives students the opportunity to learn about technology in its context of use and challenges them to consider the needs of real users as well as environmental constraints.

Two field investigations were introduced into the subject:

- A "mini-fieldwork" activity, in which students in the first week investigate a technology in the field from a complex, systems perspective (e.g., an ATM, rail ticketing machine, library catalogue, $i P o d)$ and the following week present their findings in their tutorials.

- A major fieldwork assignment which takes place over several weeks and in which students research the use of technologies in a small business (e.g., video store, gym, bookshop) and again present their findings as well as write a substantial report.

Students work unsupervised in small groups using mobile devices to take photographs of the technology, people using it and its environment of use; to make sound or video recordings as they interview users; or less often to make notes with a stylus or keyboard. Other ways of supporting learners in the field with mobile technology that have been reported in the literature, such as giving students access to online reference materials, providing them with GPS data and fostering communication between field participants (Wentzel, van Lammeren, Molendijk, de Bruin \& Wagtendonk, 2005; Kneebone \& Brenton, 2005; Sharples, Corlett \& Westmancott, 2002), were not employed here. There was no money for the development of online reference materials or to pay for usage charges. In addition to improving the students' learning experience, the fieldwork had to be easy to manage and sustainable so that it became embedded in this large, core subject.

The major fieldwork assignment remained fairly stable over time but the minifieldwork underwent three iterations to arrive at its current workable form. A detailed evaluation of Trial 1 has previously been published (Dyson, Lawrence, Litchfield \& Zmijewska, 2008), while the changes over all three trials are summarised in Table 2.

In the first trial, each team was issued with a PDA bought with money from a university infrastructure grant. Some teams additionally used their own devices, usually mobile phones or PDAs. At the end of the mini-fieldwork, students were asked to complete an evaluation, in which they listed the two best and two worst things about using the PDAs or other mobile devices in this exercise. The best aspect, according to $61 \%$ of students, was the multimedia capability of the devices, while the worst complaint was poor usability $(68.2 \%)$. Surveys of Australian university students have shown that relatively small numbers either own PDAs $(14.7 \%)$ or have access to them (18.6\%) (Bachfischer et al., 2008; Kennedy et al., 2008). Probably the sophistication of the device with multiple functionalities and several methods of activating some of these functions confused students and reduced the level of comfort in using these devices effectively, in the short time allowed during this two-week exercise. Overall, most students enjoyed the fieldwork and put a lot more work into the exercise than was expected for the small allocated mark of $3 \%$ that could be earned towards their final grade. The worst aspect of the mini-fieldwork according to the lecturer was the 
amount of time and energy she spent in issuing and keeping track of the PDAs across the entire day of classes.

Table 2: Development of the mini-fieldwork over time

\begin{tabular}{|c|c|c|c|}
\hline & $\begin{array}{c}\text { 1st trial } \\
\text { Autumn } 2007\end{array}$ & $\begin{array}{l}\text { 2nd trial } \\
\text { Spring } 2007\end{array}$ & $\begin{array}{l}\text { Final format } \\
\text { Autumn } 2008 \text { onwards }\end{array}$ \\
\hline $\begin{array}{l}\text { Implem- } \\
\text { entation }\end{array}$ & $\begin{array}{l}1 \text { PDA provided to each } \\
\text { student team }\end{array}$ & $\begin{array}{l}\text { Students use own devices } \\
\text { - Mobile phones } \\
\text { - Digital cameras } \\
\text { - Video cameras } \\
\text { - PDAs } \\
\text { - Laptops }\end{array}$ & $\begin{array}{l}\text { More explicit instructions } \\
\text { on what data to collect and } \\
\text { how to use it } \\
\& \\
\text { Students urged to bring } \\
\text { several mobile devices per } \\
\text { team }\end{array}$ \\
\hline $\begin{array}{l}\text { Problems } \\
\text { encoun- } \\
\text { tered }\end{array}$ & $\begin{array}{l}\text { Poor usability of PDAs } \\
\text { - } 68.2 \% \text { of students } \\
\text { complained of usability } \\
\text { issues } \\
\text { Logistics and security issue } \\
\text { - Excessive effort to track } \\
\text { distribution and return } \\
\text { of PDAs to ensure none } \\
\text { lost or stolen } \\
\text { Sustainability issue } \\
\text { - Cost of PDAs }\end{array}$ & $\begin{array}{l}\text { Lack of autodidactic } \\
\text { competency } \\
\text { - A number of students } \\
\text { unsure about what data } \\
\text { to collect and how to } \\
\text { incorporate it into } \\
\text { presentations } \\
\text { - Occasional students } \\
\text { unable to use own } \\
\text { devices or download or } \\
\text { share data with team } \\
\text { members }\end{array}$ & $\begin{array}{l}\text { Residual problem with a } \\
\text { few students } \\
\text { - Taking insufficient } \\
\text { photos or recordings } \\
\text { (e.g., 1) and } \\
\text { consequently losing data }\end{array}$ \\
\hline
\end{tabular}

To avoid these problems in the second trial, students were asked to use their own mobile devices instead of the university's PDAs. The term "mobile technologies" was interpreted more broadly than is often the case in m-learning: not only communication devices were included, but also other portable devices such as digital cameras and video recorders. The use of student owned equipment completely removed the security issue for the academics. However, new problems arose with students' not always knowing what to do with their devices. Some appeared unable to easily transfer their everyday competencies with their personal devices to the educational setting, and perhaps were surprised to be asked to do so. Instructions about what multimedia data they were to collect, which had been quite sufficient for the PDAs in Trial 1, were not adequate in Trial 2. This issue of lack of autodidactic competence the ability of students to know how to learn and organise their own learning processes - has been identified as a problem in m-learning (Grohmann, Hofer \& Martin, 2005). It is, at least in part, the result of unfamiliarity with m-learning, which they are probably encountering for the first time in their educational experience.

In addition, some students had mastery only of certain functions on their devices but not others they were required to use in the fieldwork. For example, a student reported that he could not take photographs with his mobile phone as he had never tried to do this before. The study by Kennedy et al. (2008) confirms that, once one goes beyond certain commonly owned mobile devices and beyond the basic uses of these devices, the technological competencies of the digital natives are much more varied than has sometimes been assumed. For example, the only mobile phone functions that have almost universal use are phone calls and text messages. This means that not every student can be assumed to know how to take a photograph or make a sound or video recording. 
As a result, more explicit instructions have since been given to the students about what data to collect, for example, what to photograph, how many photographs to take and how to incorporate them into their presentations. Student teams are also now strongly advised to bring more than one device with them, so that if one student doesn't know how to take a photograph or record an interview with their device, a team mate can step in. This has reduced the problem substantially, apart from a very small number of students who still experience difficulties. As m-learning becomes the norm, these students will probably become habituated to the sorts of tasks required of them and the issue will hopefully resolve itself. A training handout on sharing data from mobile devices is also being developed and will be placed on the subject web page. Given the success of the exercise for the vast majority, $\mathrm{m}$-fieldwork has now become a permanent feature of the subject.

\section{Case study two: Fostering interactivity in lectures using m-learning}

In order to engage students in the large lectures of core subjects, interactive m-learning activities were introduced in 2007 on a trial basis to one lecture (110 students) of the IT subject in which the $\mathrm{m}$-fieldwork was being conducted. Following the success of that trial, we commenced a full scale implementation in the lectures of the Accounting for Business subject in the Business Faculty at our university (500-1,400 students each semester divided into 3 lecture cohorts). Though lectures are hard to justify pedagogically, being highly didactic in nature, they remain a reality at most Australian universities for reasons of economy in courses which attract large student numbers. Improving interactivity in lectures has been a major focus of m-learning research around the world in recent years, largely in an attempt to make students' learning more active and overcome the reluctance of many students to engage in traditional methods of classroom interaction, such as replying to questions when asked, volunteering answers or raising hands (Slain, 2004). In a survey of student interest in $\mathrm{m}$-learning, the three main uses in class that students said they would welcome were to create more interaction with the lecturer $(64 \%)$, to make learning more fun $(42 \%)$, and to foster interaction between students (37\%) (Lawrence et al., 2008).

Fies and Marshall (2006) report on a range of mobile devices that have been employed to enhance interactivity: personal response systems involving clickers (audience response systems), PDAs, laptops and tablet PCs. Using these, lecturers can receive feedback on students' learning, ascertain levels of satisfaction with the teaching materials and methods, and conduct experiential learning using game-like sessions (Oliver, 2007; Scheele, Wessels, Effelsberg, Hofer \& Fries, 2005; Goh \& Hooper, 2007). However, one problem with all these interactive devices is the cost to the university of purchasing and maintaining them, as well as the practicality of carrying quantities of devices to large lectures. Some researchers have tried to avoid this issue by asking students to answer questions in class using their mobile phones to send text messages. However, even with SMS messages, there are student concerns over usage charges. Lindquist Denning, Kelly, Malani, Griswold \& Simon (2007) found that SMS for responding to multiple choice problems usually cost students $20-25$ cents per message, which made messaging more expensive and less attractive than traditional clickers.

In order to introduce interactivity into lectures in a way that would be cost effective and sustainable for the university, but also minimise usage costs to the student, the researchers developed the mInteract system. This relies on data transmission via either WAP/WML or HTTP technology. Students use their own Internet enabled mobile 
phones, PDAs or wireless laptops to log into the mInteract website and answer questions. They pay per packet of data transmitted rather than per byte, unlike SMS. The cost of one interaction using this form of transmission has been estimated at approximately 2 cents, compared with the 20-25 cents per message reported above. The only exception to this involves students with mobile phone plans where payment is per unit of time connected.

During a lecture (see Figure 1), an activity is chosen by the lecturer and activated (A), with responses subsequently collected (C), and results displayed (D) to the class, usually in the form of a graph. To date, lecturers have used the system for presenting questions to the class, including multiple choice quizzes and questions requiring a text based or number answer. However, the system can also accommodate peer evaluations of students' work (e.g., student presentations or posters), posting anonymous questions to the lecturer during class, and multiple selection from a list (e.g., student selection of topics they want covered in the subject).

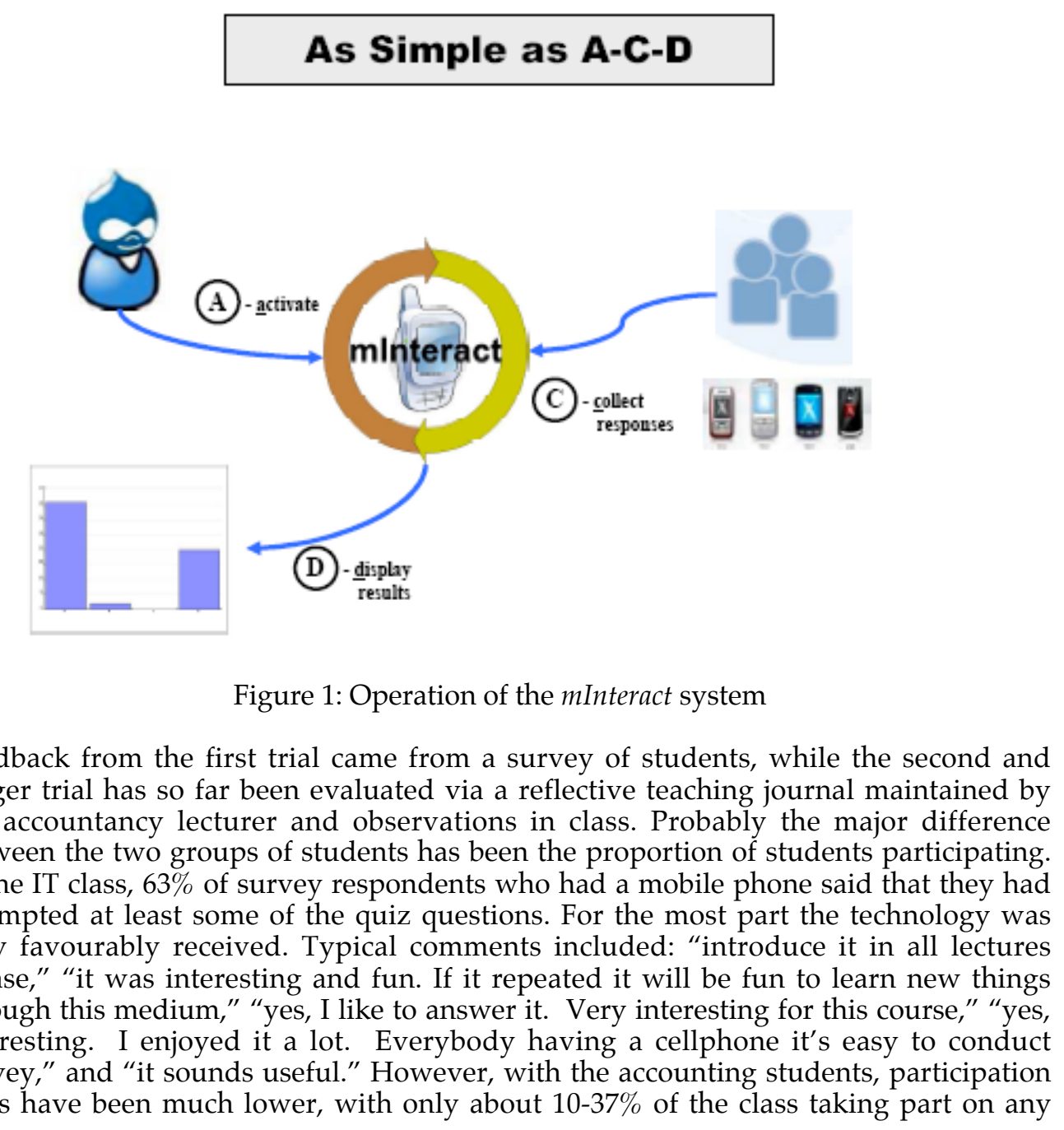


one occasion. Fewer students claim to have Internet enabled phones or other wireless devices and some students have experienced problems logging into the mInteract website. At least some of the students who say they do not have Internet enabled phones probably do not know how to access the Internet via their phones, a less obvious operation than on a desktop computer. As Kennedy et al. (2008) found, more than two-thirds of students have never used their phone to obtain information or services from the Web. In order to overcome the problem of the large proportion of students unable to use mInteract, the lecturer has been inviting these students to take part in the activities by show of hands, and this has worked well, with most students enjoying the added interaction in the lectures whether they logon to mInteract or not.

One of the most important outcomes in both trials has been the feedback that mInteract provides about students' learning. Increases in learning are very apparent through the display of results in the form of graphs, particularly where the same question is repeated at the beginning and end of the lecture. The two resulting graphs can be shown simultaneously to the students to demonstrate to them just how much they have learned during the lecture. Graphs also reveal the degree to which students have failed to understand a concept. This is important in opening a window for the lecturer into which parts of the curriculum are giving the students most difficulty and which need further work. On a number of occasions, this has resulted in the lecturer presenting further slides and clarification to the students the following week.

For the lecturer, the use of the technology in the classroom is not disruptive as each activity takes about 2 minutes for the students to complete, with the results instantly available to the lecturer, and to the class at her or his discretion. The quiz or other questions do not take a lot of time to prepare, the only caveat being that the questions and answers need to be short in order to minimise the size of data packets and the resulting cost to students.

From the researchers' point of view, mInteract has been very worthwhile. The obvious cost advantage from using students' own phones as opposed to university clickers means that mInteract is a technology that is of great potential advantage. It is likely that, as older mobile phones are phased out and more students acquire Internet enabled devices, participation rates in mInteract activities will rise. At the same time, we need to work on the issue of students who have Internet capability on their devices but don't know how to access it. In the same way that computer training is accepted as a normal part of equality of access to education, perhaps mobile device training needs to be provided as we enter the age of m-learning. At least one university in the USA has already pursued this course of action (Miertschin \& Willis, 2004).

\section{Case study three: Using mobile technology to learn about mobile technology}

Teaching IT students mobile application development and other aspects of wireless technologies is increasingly becoming part of IT programs at university, as demand for graduates in this area grows. Traditionally, students have been entirely dependent on simulation software, or emulators, installed on desktop computers to test the code they have written. The problem is that these do not always reflect exactly what the mobile device will show (Jentzsch \& Mohammadian, 2004). To provide a learning experience better situated in reality, some universities are beginning to provide mobile devices for students to program, usually PDAs or BlackBerries (Alford \& Ruocco, 2001; Mahmoud \& Dyer, 2007). 
At our university, IT students are introduced to mobile technology and wireless programming techniques in the subject Mobile Application Programming. In their practical assignment they are given a choice of programming using the $\mathrm{C \#} \mathrm{("C} \mathrm{sharp")}$ language or developing an I-mode website using PHP/HTML. In 2007, the purchase of 18 PDAs (i-mate JasJams) allowed the students learning C\# to program directly onto mobile devices, although they continued to have access to a simulator. The simulator allowed students to work on their code outside class hours since, for security reasons, access to the PDAs was only permitted in supervised laboratory sessions. The i-mate JasJams were chosen for their suitability for developing applications but, as expensive devices ( $\$ 1,100$ each) with all the latest features, were considered vulnerable to theft.

Towards the end of the first semester of students using the PDAs, they were asked to comment on several aspects of the practical assignment including the value of learning wireless programming on the PDA versus the simulator. From the 25 students enrolled in the subject, 11 who had used the PDAs completed a written survey which comprised the following combination of closed and open questions:

1. Did the use of the PDA for programming the application give added value or a better experience for you than working on the simulator alone? Please state why or why not.

2. Did using the PDAs help you understand the theory of wireless technology better? Please explain why.

3. If you were given a mobile device in class, what would you like to do with it?

4. What did you like and not like about the hands on assignment?

5. Would you like to have a booking system to allow you to take the PDAs home? Yes No

6. Any other comments.

The students' Yes/No answers to Questions 1, 2 and 5 were counted and the results are summarised in Table 3. Qualitative responses to Questions 1-4 and 6 were analysed for common themes and used to understand the students' perceptions of their learning experience.

Table 3: Quantitative results of students' evaluation of PDAs

\begin{tabular}{|c|l|c|c|c|}
\hline \multicolumn{2}{|c|}{ Question } & \multicolumn{3}{c|}{ Responses (n = 11) } \\
\cline { 3 - 5 } & Yes & No & Unsure \\
\hline 1. & PDA better for wireless programming & 9 & 2 & 0 \\
\hline 2. & PDA improves theoretical understanding & 6 & 4 & 1 \\
\hline 5. & Booking system to allow PDA use outside class & 8 & 3 & 0 \\
\hline
\end{tabular}

The responses in Table 3 show that most students perceived that learning wireless programming techniques on a mobile device was superior to learning on the simulator (Q. 1), and most would have liked to have access to the PDAs outside class time in order to gain further practice (Q. 5). Of the questions which elicited qualitative responses, 7 students further reiterated their appreciation of being able to practise on the PDAs (Q. 3), 4 students commented favourably on the opportunity to get working experience on real devices (Q. 4), while the only 3 students to add "other comments" (Q. 6) all re-emphasised the need to be able to get access to the PDAs outside class in order to practice their coding. The word that cropped up again and again in the students" responses was "real": the PDAs were real devices that gave the students a real feeling of wireless programming. Specific comments included those of 3 students 
who noted performance problems with the simulator, for example slow speed; and others noted that the PDA gave a better sense of its capabilities and the limitations of coding and designing for mobile devices, presumably in contrast to the higher performance and large screen real estate of desktop computers. Of the 2 students who answered Q. 1 negatively, one still thought that it was "COOL" to use the PDA even while maintaining that there was no appreciable difference from the simulator as both used the same programming environment; and the other, who appeared to have misread the question, stated a preference for learning wireless programming on a mobile phone instead of the PDA due to the more widespread adoption of the former and lack of any personal experience with PDAs.

In contrast to most students' appreciation of how the PDAs had contributed to their programming skills was their ambivalence about whether using the mobile devices had assisted them in understanding the theory of wireless technology (Q. 2). Only 6 students thought that using the PDAs had promoted a better theoretical understanding (see Table 3). Answers were mixed and their reasoning not always clear. One student who believed that it had helped offered the following explanation: "Yes. Because it is a wireless device and you get to experiment with it and get to know the technology better." A reason given by those who did not believe that it had improved their theoretical knowledge was the lack of time to try out the services available on the PDA. These results highlight a difficulty with the experiential theory of learning, the fact that some students fail to develop abstract concepts from their learning experience (Lai et al., 2007).

Despite this, the introduction of the PDAs was regarded as highly successful, particularly in improving the students' experience of learning wireless programming. Consequently, PDAs are still being used to teach wireless programming in this subject, with similarly favourable results. Despite the desire by many students to be able to borrow the PDAs for use outside class, it was decided not to allow this after all. The PDAs were regarded as too expensive to risk this as there was no foreseeable funding to replace them if lost.

\section{Case study four: Podcasting}

The fourth part of our research agenda was the implementation of lecture podcasts, again in the Introduction to Information Systems subject mentioned above. Because this was a first year, first semester subject, scaffolding and support for students' learning was given a high priority. Many students have difficulty making the transition from the high school learning environment to university. In addition, there is the problem that many international students experience adapting to the Australian learning environment. This issue is exacerbated with core first year subjects, which tend to have larger numbers of students and where students are compelled to take the subject whether they are interested in the topic or not. Podcasts provide a large-scale method of supporting new students by making learning materials accessible beyond classroom hours. In the U.S.A., podcasts are being used and trialled extensively in universities such as Stanford University (Townend, 2005) and Duke University (Belanger, 2005).

While some academics are using podcasts to replace face to face lectures (Stothart, 2006), in this subject they were used merely to supplement lectures, which students were still encouraged to attend. Specially scripted audio summaries of the 1.5-hour lectures were recorded by the lecturer. In order to make the recordings as professional as possible, the script was prepared before recording and this took some time to 
construct. For an average lecture it took 0.5 day to script, record, edit, convert to MP3 format, and upload the podcasts. However, some complex lectures could take a whole day where students were struggling with difficult concepts and extra explanatory material needed to be added. Following compression the podcast files were uploaded each week to a folder on the university Blackboard e-learning system since automatic RSS feeds were not available. Students could download the files to their MP3 players, $i$ Pods or more usually PCs, whenever they wished following the lecture.

Since a complete evaluation of the podcasts has previously been published (Nataatmadja \& Dyson, 2008), just the main points will be highlighted here. Only 36\% of surveyed students used the podcasts one time or more, mostly because it helped their understanding and filled in gaps. The main reason given for not using them $(25 \%$ of negative responses) was that they had attended all lectures and made notes. The lack of automatic feeds may have further contributed to the low usage rate. The most interesting finding was that some international students found the podcasts very useful for overcoming language difficulties: "I am an international students, I cannot understand everything in the class. So I can listen the AS [audio summaries] after class. It is useful"; "Yes, it help me to review the lecture when I was confused with some point. And it help me to enhance the ability of English listening because I am Chinese" (Nataatmadja \& Dyson, 2008, p. 20).

Of the four m-learning implementations presented in this paper, the researchers viewed the podcasts as the least successful. Despite their usefulness to a minority of students, they did not promote experiential learning. Podcasts as implemented here are a one way, transmission mode of learning reminiscent of the traditional didactic, teacher centred approach. Moreover, though the podcasts were sustainable as far as cost was concerned - all the lecturer needed was an audio recorder and the existing elearning system, while the students used their own players or PCs - the amount of time required to produce the podcasts was only acceptable to the lecturer as a one-off effort. Hence the podcast summaries have remained unchanged since the first iteration of the subject.

More research needs to be carried out on how podcasts can be improved to include activities to promote deeper thinking in our students and support active learning. Our next experiment in this area in late 2009 will be an exercise in which student teams create podcasts and vodcasts (video podcasts) of interviews with IT professionals and share these with their fellow students to increase awareness of career options. Student generated podcasts have been successfully implemented in university courses elsewhere and shown to improve learning and metacognition (McLoughlin, Lee \& Chan, 2006).

\section{Conclusion}

How the four case studies match the criteria established at the beginning of our research is summarised in Table 4. In this article, we have demonstrated how mlearning can support active, educational experiences through fieldwork and through teaching students about mobile technology. We have also shown how it can improve the learning experience of students in large lectures by allowing them to interact with the lecturer, contribute to joint class responses shown on the screen, and make learning more interesting and fun. 
Table 4: Evaluation summary of the m-learning research agenda against key criteria

\begin{tabular}{|c|c|c|c|c|}
\hline \multirow[b]{2}{*}{ Criteria } & \multicolumn{4}{|c|}{ Case studies } \\
\hline & M-fieldwork & $\begin{array}{l}\text { Interactive } \\
\text { lectures using } \\
\text { mInteract }\end{array}$ & $\begin{array}{c}\text { Mobile application } \\
\text { development with } \\
\text { PDAs }\end{array}$ & $\begin{array}{l}\text { Lecture } \\
\text { summary } \\
\text { podcasts }\end{array}$ \\
\hline $\begin{array}{l}\text { Experiential } \\
\text { learning }\end{array}$ & $\checkmark$ & $\checkmark$ & $\checkmark$ & $\begin{array}{c}\mathbf{x} \\
\text { Repeats old } \\
\text { transmission } \\
\text { model of } \\
\text { education }\end{array}$ \\
\hline $\begin{array}{c}\text { Economic } \\
\text { sustainability }\end{array}$ & $\begin{array}{c}\checkmark \\
\text { Became } \\
\text { sustainable when } \\
\text { student owned } \\
\text { devices replaced } \\
\text { university owned } \\
\text { devices }\end{array}$ & $\begin{array}{c}\checkmark \\
\text { Student owned } \\
\text { devices }\end{array}$ & $\begin{array}{c}\text { ? } \\
\text { University owned } \\
\text { devices; } \\
\text { sustainable only if } \\
\text { use of devices } \\
\text { controlled and not } \\
\text { issued out of class }\end{array}$ & $\begin{array}{c}\checkmark \\
\text { Student owned } \\
\text { devices or } \\
\text { university PCs }\end{array}$ \\
\hline $\begin{array}{l}\text { Practical } \\
\text { feasibility }\end{array}$ & $\begin{array}{c}\checkmark \\
\text { Easy to run once } \\
\text { lecturer moved to } \\
\text { student owned } \\
\text { devices }\end{array}$ & $\begin{array}{c}\text { ? } \\
\text { Quick to } \\
\text { implement for } \\
\text { lecturer but } \\
\text { usability } \\
\text { problems for } \\
\text { some students }\end{array}$ & $\checkmark$ & $\begin{array}{c}\boldsymbol{?} \\
\text { Easy to implement } \\
\text { but impractical } \\
\text { from a time point } \\
\text { of view when } \\
\text { podcasts require } \\
\text { updating }\end{array}$ \\
\hline $\begin{array}{c}\text { Other } \\
\text { considerations }\end{array}$ & $\begin{array}{c}\checkmark \\
\text { Teaching IT and } \\
\text { Business students } \\
\text { about IT in a real } \\
\text { life context }\end{array}$ & $\begin{array}{c}\checkmark \\
\text { Engaging } \\
\text { students in large } \\
\text { lectures }\end{array}$ & $\begin{array}{c}\checkmark \\
\text { Teaching IT } \\
\text { students about IT } \\
\text { more effectively }\end{array}$ & $\begin{array}{c}\checkmark \\
\text { Support for } \\
\text { students' learning, } \\
\text { particularly for } \\
\text { international } \\
\text { students }\end{array}$ \\
\hline
\end{tabular}

Implementing our research agenda has forced us to interrogate the assumptions behind one form of m-learning that has been very widely promoted, that is podcasting, with its mantra of learning "anywhere, anytime". From our observations, if students are able and motivated to attend class, lecture podcasts will be used only by a minority of students. Lecture podcasts fail to improve the learning experience for the majority and so fail to engage them. The time factor in preparing any podcasts other than unedited recordings of lectures is also a potential problem for busy academics, particularly if the results are so unimpressive. Other applications of this potentially useful form of mobile technology need to be considered, such as student generated podcasts in preference to lecturer generated ones. These may promote deeper learning and move to a student centred approach. Thus, though m-learning lends itself to a more active approach to education, it does not automatically guarantee that good learning will occur. We need to carefully interrogate our investigations of m-learning to ensure that it is not just a case of technology for technology's sake, but is adding to the educational experience of our students in a meaningful way.

One of the most important outcomes of our research is that embedding active, experiential m-learning into mainstream courses on a permanent basis is possible. This can be achieved by paying attention to economic sustainability - for example, by minimising costs through the use of student owned devices - and also ensuring that the effort required by the lecturer is not excessive. As quoted from Traxler (2005, p. 
182) earlier, "quick-and-dirty ... not intimidating" is often a good course to pursue. Our implementation of m-fieldwork is an example of how introducing a single dimension of mobile technology (multimedia recording) and perfecting this over time has been effective for the students' learning experience as well as practical for the lecturer.

Our future work will need to focus on embedding these m-learning initiatives on a wider scale and across a greater range of subjects. Institutional support will no doubt have to be part of this, and has already begun at our university with the establishment of an officially supported Podcasting Community interest group and the provision of grants to fund m-learning and other educational research projects. Academic staff development will be necessary to sustain large-scale change in this area. Technology support will also be needed, particularly for the development of new mobile applications and teaching and learning resources. Most importantly, universities will have to be proactive in seizing the many learning opportunities offered by these ubiquitous devices so that the experience of our students is enriched and better aligned with their current interests and technological practice.

\section{Acknowledgments}

We thank the University of Technology, Sydney, for providing us with the infrastructure grant to purchase the PDAs which assisted us in commencing our m-learning research. We also warmly thank Jonathan Tyler and his students, Business Faculty, UTS, for allowing us to implement mInteract in their subject.

\section{References}

Alford, K. L. \& Ruocco, A. S. (2001). Integrating personal digital assistants (PDAs) into a computer science curriculum. Proceedings of the 31st ASEE/IEEE Frontiers in Education Conference (p. F1C-19). Nevada, 10-13 October.

Belanger, Y. (2005). Duke University iPod First Year Experience Final Evaluation Report, pp. 1-15. http:/ / cit.duke.edu/pdf/ipod_initiative_04_05.pdf [viewed 23 April 2009].

Bachfischer, A., Lawrence, E., Litchfield, A., Dyson, L. E. \& Raban, R. (2008). Student perspectives about using mobile devices in their studies. IADIS International Conference on Mobile Learning (pp. 43-50). Algarve, 11-13 April.

Bruner, J. S. (1966). Toward a theory of instruction. Cambridge, M.A.: Harvard University Press.

Dyson, L. E., Lawrence, E., Litchfield, A. J. \& Zmijewska, A. (2008). M-fieldwork for information systems students. Proceedings of the Forty-First Annual Hawaii International Conference on System Sciences (HICSS) (pp. 1-10). Waikoloa, 7-10 January.

Dyson, L. E., Raban, R., Litchfield, A. J. \& Lawrence, E. (2008). Embedding m-learning into mainstream educational practice: Overcoming the cost barrier. 4th International Conference on Interactive Mobile and Computer Aided Learning (IMCL2008) (pp. 1-9). Amman, 16-18 April.

Fies, C. \& Marshall, J. (2006). Classroom response systems: A review of the literature. Journal of Science Education and Technology, 15(1), 101-109.

Goh, T. \& Hooper, V. (2007). To TxT or not to TxT: That's the puzzle. Proceedings of the 2007 Informing Science and IT Education Joint Conference. Ljubljana, 22-25 June. [see Journal of Information Technology Education, 6, 441-453. http:/ /jite.org/ documents/Vol6/JITEv6p441453Goh283.pdf] 
Grohmann, G., Hofer, A. \& Martin, G. (2005). ARIS MOBILE: Helping to define the future of mobile learning. In W. Brookes, E. Lawrence, R. Steele \& E. Chang (Eds), Proceedings of the International Conference on Mobile Business (ICMB) (pp. 213-219). Sydney, 11-13 July.

Herrington, A. \& Herrington, J. (2007). Authentic mobile learning in higher education. Australian Association for Research in Education (AARE) 2007 Conference (pp. 1-9). Fremantle. http: / / www.aare.edu.au/07pap/her07131.pdf

Jentzsch, R. \& Mohammadian, M. (2004). A framework for teaching mobile and wireless technology. Journal of Issues in Informing Science and Information Technology, (1), 11-22. http: / / informingscience.org/ proceedings/InSITE2004/012jentz.pdf

JISC (Joint Information Systems Committee) (2005). Innovative practice with e-Learning: A good practice guide to embedding mobile and wireless technologies into everyday practice. London: JISC. http:/ / www.jisc.ac.uk/uploaded_documents/publication_txt.pdf [viewed 30 April 2009].

Kay, R. \& Dyson, L. E. (2006). Learning to collaborate and collaborating to learn: An experiential approach to teaching collaborative systems. Journal of Theoretical and Applied Electronic Commerce Research, 1(2), 36-44.

Kennedy, G. E., Judd, T .S., Churchward, A., Gray, K. \& Krause, K.-L. (2008). First year students' experiences with technology: Are they really digital natives? Australasian Journal of Educational Technology, 24(1), 108-122. http:/ / www.ascilite.org.au/ajet/ajet24/kennedy.html

Kneebone, R. \& Brenton, H. (2005). Training perioperative specialist practitoners. In A. Kukulska-Hulme \& J. Traxler (Eds), Mobile learning: A handbook for educators and trainers (pp. 106-115). Milton Park: Routledge.

Kolb, D. (1984). Experiential learning: Experience as the source of learning $\mathcal{E}$ development. Englewood Cliffs: Prentice-Hall.

Kukulska-Hulme, A. \& Traxler, J. (Eds) (2005). Mobile learning: A handbook for educators and trainers. London: Routledge.

Lai, C.-H., Yang, J.-C., Chen, F.-C., Ho, C.-W. \& Chan, T.-W. (2007). Affordances of mobile technologies for experiential learning: The interplay of technology and pedagogical practices. Journal of Computer Assisted Learning, 23, 326-337.

Laouris, Y. \& Eteokoeous, N. (2005). We need an educationally relevant definition of mobile learning. Proceedings of the 4th World conference on mLearning (mLearn 2005) (pp. 1-13). Cape Town, 25-28 October. http:/ / www.mlearn.org.za/CD/ papers/Laouris $\% 20 \& \% 20$ Eteokleous.pdf

Lave, J. \& Wenger, E. (1991). Situated learning: Legitimate peripheral participation. Cambridge, U.K.: Cambridge University Press.

Lawrence, E., Bachfischer, A., Dyson, L.E. \& Litchfield, A. (2008). Mobile learning and student perspectives: An mReality check! 7th International Conference on Mobile Business (pp. 287-295). Barcelona, 7-8 July.

Lindquist, D., Denning, T., Kelly, M., Malani, R., Griswold, W.G. \& Simon, B. (2007). Exploring the potential of mobile phones for active learning in the classroom. Proceedings of the 38th SIGCSE Technical Symposium on Computer Science Education, 39(1), 384-388. Kentucky, 7-10 March.

Litchfield, A .J., Dyson, L. E., Lawrence, E. \& Zmijewska, A. (2007). Directions for m-learning research to enhance active learning. In ICT: Providing choices for learners and learning: Proceedings ascilite Singapore 2007. http: / / www.ascilite.org.au/conferences/ singapore07/procs/litchfield.pdf 
Litchfield, A., Nettelton, S. \& Taylor, T. (2008). Integrating work-ready learning into the curriculum contextualised by profession. Proceedings of the ACEN-WACE Asia Pacific Conference "Work integrated learning (WIL): Transforming Futures" Conference (pp. 340-347), Sydney, 30 September-October 2008.

McLoughlin, C., Lee, M. J. W. \& Chan, A. (2006). Fostering reflection and metacognition through student generated podcasts. Proceedings of ACEC (pp. 1-8), Cairns, 2-4 October. [verified 3 May 2009] http:/ / csusap.csu.edu.au/ achan/papers/2006_POD_ACEC.pdf

Mahmoud, Q. H. \& Dyer, A. (2007). Integrating BlackBerry wireless devices into computer programming and literacy courses. In D. Dicheva (Ed), Proceedings of the ACM Southeast Conference (ACMSE'07) (pp. 495-500). Winston-Salem, 23-24 March.

Marton, F. \& Booth, S. (1997). Learning and awareness. New Jersey: Lawrence Erlbaum Assoc.

Miertschin, S. L. \& Willis, C. (2004). Mobile computing in the freshman computer literacy course: What impact? Proceedings of SIGITE'04 (pp. 149-152), Salt Lake City, 28-30 October.

Naismith, L., Lonsdale, P., Vavoula, G. \& Sharples, M. (2004). Literature review in mobile technologies and learning, Report 11. Bristol: Futurelab. [verified 3 May 2009] http: / / www.futurelab.org.uk/ resources / documents / lit_reviews/Mobile_Review.pdf

Nataatmadja, I. \& Dyson. L. E. (2008). The role of podcasts in students' learning. International Journal of Interactive Mobile Technologies, 2(3), 17-21. [verified 3 May 2009] http: / / onlinejournals.org/i-jim/article/view/526

Oliver, B. \& Goerke, V. (2007). Australian undergraduates' use and ownership of emerging technologies: Implications and opportunities for creating engaging learning experiences for the Net Generation. Australasian Journal of Educational Technology, 23(2), 171-186. http:/ / www.ascilite.org.au/ajet/ajet23/oliver.html

Oliver, R. (2007). Using mobile technologies to support learning in large on campus university classes. In ICT: Providing choices for learners and learning: Proceedings ascilite Singapore 2007. http:/ / www.ascilite.org.au/conferences/ singapore07/procs/oliver.pdf

Prosser, M. \& Trigwell, K. (1999). Understanding learning and teaching: The experience in higher education. Buckingham: Open University Press.

Ramsden, P. (1992). Learning to teach in higher education. London: Routledge.

Scheele, N., Wessels, A., Effelsberg, W., Hofer, M. \& Fries, S. (2005). Experiences with interactive lectures: Considerations from the perspective of educational psychology and computer science. Proceedings of the 2005 Conference on Computer Support for Collaborative Learning (pp. 547-556). Taipei, 30 May-4 June.

Sharples, M., Corlett, D. \& Westmancott, O. (2002). The design and implementaiton of a mobile learning resource. Personal and Ubiquitous Computing, 6, 220-234. London: Springer-Verlag.

Sharples, M., Taylor, J. \& Vavoula, G. (2005). Towards a theory of mobile learning. Proceedings of the 4th World conference on mLearning (mLearn 2005) (pp. 1-8). Cape Town, 25-28 October. http:/ / www.mlearn.org.za/CD/papers/Sharples-\%20Theory\%20of\%20Mobile.pdf

Slain, D. (2004). An interactive response system to promote active learning in the Doctor of Pharmacy curriculum. American Journal of Pharmaceutical Education, 68(5), 1-9.

Stothart, C. (2006). Do the iPod shuffle, but don't miss the lecture. The Times Higher Education Supplement, 26 May. http:/ / thes.co.uk/ current_edition/story.aspx?story_id=2030201 [viewed 6 Nov 2007; n.a. 3 May 2009] 
Townend, N. (2005). Podcasting in higher education. Viewfinder, Media Online Focus, British Universities Film \& Video Council, 61(December), i-iv.

Traxler, J. (2005). Institutional issues: Embedding and supporting. In A. Kukulska-Hulme \& J. Traxler (Eds), Mobile learning: A handbook for educators and trainers (pp. 173-188). London: Routledge.

Wentzel, P., van Lammeren, R., Molendijk, M., de Bruin, S. \& Wagtendonk, A. (2005). Using mobile technology to enhance students' educational experiences. EDUCAUSE, ECAR Case Study 2 (1-18). Boulder, Colorado. [verified 3 May 2009] http: / / net.educause.edu/ir/library/pdf/ers0502/cs/ecs0502.pdf

Dr Laurel Evelyn Dyson, Andrew Litchfield, Associate Professor Elaine Lawrence, Dr Ryszard Raban, Dr Peter Leijdekkers

Faculty of Engineering and Information Technology

University of Technology Sydney

PO Box 123, Broadway NSW 2007, Australia

Email: Laurel.E.Dyson@uts.edu.au, ajl@it.uts.edu.au, elaine@it.uts.edu.au,

richard@it.uts.edu.au, peterl@it.uts.edu.au 